\title{
Decision-Making Process of Prospective International Students: a Proposed Generic Complementary Model
}

\author{
Sandra Haas * and Florence Terryn
}

\section{Zusammenfassung}

Der globale Bildungsmarkt entwickelt sich rasant und die Anzahl an Studierenden ist in den letzten Jahren signifikant gestiegen. Trotz dieser positiven Entwicklung sehen sich deutsche Hochschulen einem intensiven internationalen Wettbewerb ausgesetzt. Potentielle Studierende können aus einer breiten Anzahl von Studienangeboten wählen und bewerben sich an mehreren Hochschulen parallel. Der vorliegende Beitrag soll das Hochschulmarketing in der Anwerbung internationaler Studierender unterstützen, indem ein Studienentscheidungsmodell inklusive beeinflussender Faktoren vorgestellt wird. Unter Anwendung qualitativer Inhaltsanalysen wurden sowohl theoretische Konzepte im Themenfeld als auch neuere empirische Studien zur Konzeptentwicklung herangezogen.

\section{Abstract}

The global education market is rapidly expanding and the number of students has increased significantly over the last years. Despite this positive development, German universities are affected by a high international competition. Prospective students can choose of a broad variety of educational products and will apply at several universities at the same time. To support marketing departments of higher education institutions, the paper provides a generic conceptual model on the decision-making process of potential international students including influencing parameters. Applying a scoping study and content analyses, the concept bases upon theoretical concepts in this field but also the latest empirical findings.

\section{Introduction}

According to a study by Ken Research and Euromonitor International, the global education industry is not only among the largest sectors worldwide but also one of the fastest developing (Euromonitor International 2017, Ken Research 2011). Hereby, the global higher education market plays a significant role: The number of students has more than doubled between 2000 and 2014 (207 million) (UNESCO 2017). In 2009, China, India, the US and Russia have a combined share of 45 per cent of total global tertiary enrolments (British Council 2012). "A key feature of the global tertiary education sector has been the growth in internationally mobile students. Their number has risen from 800,000 in the mid-1970s to over 3.5 million in 2009" (British Council 2012: 4). In 2016, there were about 3.5 million foreign students within OECD areas (OECD 2018). Despite an incre- ased share of foreign students among freshmen at German higher education institutions (hereinafter: HEls) (2004: 19,5\%; 2016: 24,8\%, (Statista 2018)) and almost no study fees, Germany still ranks below countries like the US, the UK, Australia and France (British Council 2012) with respect to the number of foreign students enrolled. According to a report by UNESCO, private universities in particular benefit from the global market growth (UNESCO 2017) although it did not change the disparity of access to college (across 76 countries, $20 \%$ of the richest $25-29$ year olds had completed at least four years of higher education, compared with less than $1 \%$ of the poorest (Bagri 2017). As the demand for higher education is going to rise in the future, German governments and (public) HEls have to respond adequately, to secure German HEI will not be left behind.
It is important to understand that HEls in today's globalized world are considered businesses, whether they are profit or non-profit, private or public organizations (Hemsley-Brown \& Oplatka 2006). Therefore, HEls employ the same methods and tools that have been endorsed in the business world and use marketing to identify and satisfy the needs and wants of their customers - potential international students (hereinafter: PIS). "Globalization and market pressure in the education sector have propelled higher education institutions to constantly review on the need of economic accountability and performance improvement, many universities aim to increase the number of students admitted as a means of increasing their income while the admitted students are considered as customers" (Watjatrakul 2014: 676). Farjam and Hongyi consider students to be "consumers in higher education," who "exist in positional market, where institutions 
compete for the best students while the applicants compete for the most preferred institutions" (Farjam \& Hongyi 2015: 72). Understanding students as customers and attracting PIS with marketing programs sounds simple. In fact, it is quite a challenge:

- "Across the European Union, higher education institutions are operating in an increasingly competitive environment. Nowhere is this more apparent than in the area of international student recruitment, where increased student mobility combined with an increase in the number of institutions offering Eng- lish-language degrees has created more choice than ever before for international students." (QS Enrolment Solutions 2017) Setting up appropriate marketing programs is not only seen as a competence by $\mathrm{HEl}$ anymore, it is performed \& supported by regional and national governments as well (Cubillo et al. 2006, GATE-Germany 2018b). The UK Government is said to have sponsored several initiatives to become the world's leading nation in international education (Binsardi \& Ekwulugo 2003).
- The "decision to study overseas is one of the most significant and expensive initiatives that students may ever undertake" (Cubillo et al. 2006: 102 referring to Mazzarol 1998) and international education is not a frequently purchased service by this target group (Nicholls et al. 1995, Cubillo et al. 2006). Hereby students will consider various aspects in addition to the program offered by a foreign HEl (like safety, security, cultural activities, country image etc.) (QS Enrolment Solutions 2017, 2018).

Tab. 1) Arksey and O'Malley framework stages for the conduct of scoping reviews combined with a description of the performed stages (Colquhoun et al. 2014).

Arksey \& O’Malley

framework stage research question

\#2 Identifying relevant studies

\#3 Study selection
Description of scoping review stage

Research question:

Which conceptual frameworks on the decision making process on study choices or studying abroad exist within literature?

(1) How can the identified decision processes be characterized with regard to sequences and integrated influencing parameters?

(2) Looking at similarities and differences, which generic concept can be derived? Are further specification of the generic concept necessary?

Google Scholar is used as a main database to retrieve useful sources. First, a general search was conducted looking for literature about the student decision-making process as a whole (key words: 'student decision process', 'student higher education choice process', 'university decision', 'international student choice'). Studies written in English are looked at and no restriction of time is made. Synonyms like 'decision' and 'choice'; 'higher education' and 'university'; 'international', 'abroad' and foreign; are used to iterate the research. Based on this first round of searching, the student decision-making process is identified as a complex multi-stage choice operation with various influencing factors. Subsequently the research is concentrated on integrated - incorporating multiple, versatile types of influencing factors rather than focusing on one specific. Thereafter, a composition is made of secondary studies that provide an overview of the available literature in the field as well as primary studies that offer a self-developed model, based on empirical research. Also backwards snowballing is used as a technique, looking at the sources of the most relevant studies. In the end, a list of twenty studies was constructed.

In order to select relevant studies systematically, inclusion and exclusion criteria were set up. The first exclusion happened in the searching phase, based on the title and the abstract not containing the keywords searched for. In a second stage, only studies that meet one or more of the following criteria are selected:

a. the decision-making process is not concentrated on just one particular stage, different parameters, factors or influences are dealt with)

b. the model presented has a cyclic nature or consists of several consecutive steps;

c. a schematic model or graphic representation is offered;

d. international students are perceived as a group (excluded are studies focused on specific nationality or country of origin);

e. Factors for higher education institution independent of home country are examined, unless if Europe (or Germany) is focused upon as destination. 
- According to the latest study by QS Enrolment Solutions, a vast majority of potential international students will consider five universities or fewer. Around one quarter of PIS will apply to six or more (QS Enrolment Solutions 2018).

To support German HEls in meeting these challenges, the DAAD (= German Academic Exchange Service) has set up different research and supporting programs (GATE-Germany 2018a).

However, these programs do not fully support HEI marketing departments in understanding the decision-making process of PIS. Knowledge of the decision-making process and its influencing factors are a central prerequisite for at- tracting PIS to study programs at German HEls. The purpose of this paper is to propose a generic conceptual model on the decision-making process of PIS including influencing parameters. Our work will be based upon theoretical concepts in this field but also the latest empirical findings.

\section{Theoretical perspectives on decisi- on-making processes of prospective international students}

\subsection{Methods}

To summarize and structure the existing theoretical knowledge on decision-making processes of PIS, a scoping study was performed. "A scoping review or scoping study is a form of knowledge synthesis that addresses an exploratory research question aimed at mapping key concepts, types of evidence, and gaps in research related to a defined area or field by systematically searching, selecting, and synthesizing existing knowledge." (Colquhoun et al. 2014: 1292-1293). This research method was applied by using the methodological steps outlined in the Arksey and O'Malley (2005) framework:

Following the first stages of the scoping study, seven models were selected for further analysis (see Tab. 2). It needs to be stated here that a large majority of the identified sources are older than 20 years. Only the concept by Oliveira \&

Tab. 2) Selected theoretical concepts on the student decision-making process.

\begin{tabular}{|c|c|c|c|c|c|c|}
\hline $\begin{array}{l}\text { Age of } \\
\text { concept }\end{array}$ & Author & Year & $\begin{array}{l}\text { Title of the conceptual } \\
\text { framework }\end{array}$ & Research Approach & $\begin{array}{l}\text { Popula- } \\
\text { tion }\end{array}$ & $\begin{array}{l}\text { Integration } \\
\text { of para- } \\
\text { meters }\end{array}$ \\
\hline$\leq 10$ years & $\begin{array}{l}\text { Oliveira \& } \\
\text { Soares }\end{array}$ & 2016 & $\begin{array}{l}\text { Conceptual Model for } \\
\text { the decision process of } \\
\text { international students }\end{array}$ & $\begin{array}{l}\text { Literature Review \& Quali- } \\
\text { tative Study (interview with } \\
\text { currently enrolled students } \\
\text { in engineering programs at } \\
\text { a public university in North } \\
\text { of Portugal) }\end{array}$ & PIS & $x$ \\
\hline \multirow{4}{*}{$\begin{array}{l}11-20 \\
\text { years }\end{array}$} & $\begin{array}{l}\text { Vrontis } \\
\text { et al }\end{array}$ & 2007 & $\begin{array}{l}\text { Concept a: Preliminary } \\
\text { integrated generic hig- } \\
\text { her education student- } \\
\text { choice model }\end{array}$ & $\begin{array}{l}\text { Generic Concept build upon } \\
\text { Jackson (1982); Chapman } \\
\text { (1986) \& Hanson and } \\
\text { Litten's (1989) }\end{array}$ & US/CA & $x$ \\
\hline & $\begin{array}{l}\text { Vrontis } \\
\text { et al }\end{array}$ & 2007 & $\begin{array}{l}\text { Concept b: A contem- } \\
\text { porary higher educa- } \\
\text { tion student-choice } \\
\text { model for developed } \\
\text { countries }\end{array}$ & Conceptional Model & $\begin{array}{l}\text { Students } \\
\text { from de- } \\
\text { veloped } \\
\text { coun- } \\
\text { tries }\end{array}$ & $x$ \\
\hline & $\begin{array}{l}\text { Cubillo } \\
\text { et al }\end{array}$ & 2006 & $\begin{array}{l}\text { A model of internati- } \\
\text { onal students' prefe- } \\
\text { rences }\end{array}$ & Conceptional Model & PIS & $x$ \\
\hline & Perna & 2006 & $\begin{array}{l}\text { Conceptual model of } \\
\text { student college choice }\end{array}$ & Conceptional Model & US & $x$ \\
\hline $\begin{array}{c}21-30 \\
\text { years }\end{array}$ & $\begin{array}{l}\text { Hanson } \\
\text { \& Litten }\end{array}$ & 1989 & $\begin{array}{l}\text { Mapping the road to } \\
\text { academe }\end{array}$ & Conceptional Model & n.d. & $x$ \\
\hline \multirow[t]{3}{*}{$>30$ years } & $\begin{array}{l}\text { Hossler \& } \\
\text { Gallagher }\end{array}$ & 1987 & $\begin{array}{l}\text { Three-Phase model of } \\
\text { college choice }\end{array}$ & $\begin{array}{l}\text { Generic Concept build } \\
\text { upon Alexander (1978); } \\
\text { Anderson, Bowman,and } \\
\text { Tinto (1972); Jackson } \\
\text { (1982); Litten (1982); } \\
\text { Chapman (1981) }\end{array}$ & US/CA & $x$ \\
\hline & Chapman & $\begin{array}{l}1981 \\
1986\end{array}$ & $\begin{array}{l}\text { A behavior model of } \\
\text { the college selection } \\
\text { process }\end{array}$ & Behavioral Model & $\mathrm{CA}$ & $X$ \\
\hline & Jackson & 1982 & $\begin{array}{l}\text { Combined student } \\
\text { choice model }\end{array}$ & Conceptional Model & US & $x$ \\
\hline
\end{tabular}


Soares (2016) was published within the last five years.

\subsection{Findings}

The identified theoretical concepts were examined in a descriptive analytical manner with respect to: (1) the general research approach; (2) sequences and (3) presented influencing factors of the decision making process of PIS (= stage 4 "Charting the data" of the scoping study according to Arksey \& O'Malley (2005), see Colquhouna et al. 2014). In the following chapters, results of the performed scoping study will be presented.

\subsubsection{General research approach}

With regard to the general research approach it needs to be stated that a large majority represent conceptual models, either own creations or generic concepts resting upon existing concepts in that field (see Tab. 2). Moreover, only the concepts by Cubillo et al. (2006) and Oliveira \& Soares (2016) address decision-making practices of PIS in particular. All of the reviewed concepts included parameters of decision-making.

\subsubsection{Stages of the decision-making processes}

Except for the concept of Perna (2006) and Cubillo et al. (2006), all reviewed processes span three or five stages. Five-stage concepts suggest strong dependences on the traditional decisionmaking process of consumers in general (Kotler et al. 2008). Perna "uses the term 'college choice' to refer to all phases" (Perna 2006, p. 101) of the decision-making process. Her concept centers around an evaluation of expected monetary and non-monetary benefits and expected costs, whereby evaluations are "influenced by an individual's academic preparation for college and availability of resources to pay the costs of attendance" (Perna 2006: 116). To evaluate similarities and differences in the order of stages, all stages were colored based on content similarities (see Tab. 3).
Most of the concepts begin with the recognition of a need to study which can turn into aspirations to study abroad. According to Oliveira \& Soares (2016), students' main motivation for leaving their country of origin is the goal of seeking an international experience for personal, academic and professional development. Following the stage "Need recognition \& aspirations to study abroad", PIS most likely start to search for information (about studying abroad in general, HEl, study programs etc.) to satisfy their needs (=Search Stage). Jackson (1982) did not include a search stage. Within the concept by Hanson \& Litten (1989) as well as in the generic concept by Vrontis et al. (2007) a distinction between "locating information" and "gathering information" is made. In the latter case, this may be caused by building upon student decision-making processes from the 1980s. In the same sense Chapman (1986) and Hanson \& Litten (1989) assumed that prospective students form a set of potential HEls before their search. As information-seeking processes have

Tab. 3) Comparison of stages of identified student decision-making processes.

\begin{tabular}{|c|c|c|c|c|c|c|c|c|}
\hline $\begin{array}{l}\text { Jackson } \\
\text { (1982) }\end{array}$ & $\begin{array}{c}\text { Chapman } \\
(1981 \& \\
1986)\end{array}$ & $\begin{array}{l}\text { Hanson } \\
\text { \& Litten } \\
\text { (1989) }\end{array}$ & $\begin{array}{l}\text { Hossler and } \\
\text { Gallagher } \\
\text { (1987) }\end{array}$ & $\begin{array}{l}\text { Perna } \\
(2006)\end{array}$ & $\begin{array}{c}\text { Cubillo et al } \\
\text { (2006) }\end{array}$ & $\begin{array}{l}\text { Vrontis } \\
\text { Generic } \\
\text { Model } \\
(2007)\end{array}$ & $\begin{array}{c}\text { Vrontis Con- } \\
\text { temporary } \\
\text { Model } \\
(2007)\end{array}$ & $\begin{array}{l}\text { Oliveira } \\
\text { \& Soares } \\
(2016)\end{array}$ \\
\hline $\begin{array}{c}\text { I } \\
\text { Preference } \\
\text { stage (edu- } \\
\text { cational } \\
\text { aspiration) }\end{array}$ & $\begin{array}{c}\text { I } \\
\text { Pre-search } \\
\text { stage (List of } \\
\text { considered } \\
\text { colleges) }\end{array}$ & $\begin{array}{c}\text { I } \\
\text { Having } \\
\text { college aspi- } \\
\text { rations }\end{array}$ & $\begin{array}{c}\text { I } \\
\text { Pre-dis- } \\
\text { position } \\
\text { (Determina- } \\
\text { tion of study } \\
\text { aspiration) }\end{array}$ & \multirow{5}{*}{$\begin{array}{l}\text { Evaluation } \\
\text { of expected } \\
\text { monetary } \\
\text { and non- } \\
\text { monetary } \\
\text { benefits and } \\
\text { expected } \\
\text { costs }\end{array}$} & \multirow{5}{*}{$\begin{array}{l}\text { Purchase } \\
\text { Intention } \\
\text { of PIS re- } \\
\text { garding the } \\
\text { destination } \\
\text { country as } \\
\text { provider of } \\
\text { the educa- } \\
\text { tion service }\end{array}$} & $\begin{array}{c}\text { I } \\
\text { College } \\
\text { aspirations }\end{array}$ & $\begin{array}{c}\text { I } \\
\text { Need } \\
\text { Recognition }\end{array}$ & $\begin{array}{c}\text { I } \\
\text { Need } \\
\text { recognition }\end{array}$ \\
\hline \multirow[b]{2}{*}{$\begin{array}{l}\text { II } \\
\text { Excluding } \\
\text { institutions } \\
\text { from the } \\
\text { prospective } \\
\text { list }\end{array}$} & II & \multirow{2}{*}{$\begin{array}{c}\text { II } \\
\text { Investiga- } \\
\text { tion of HE } \\
\text { and creation } \\
\text { of set of } \\
\text { candidates } \\
\text { (sub-phase: } \\
\text { Searching } \\
\text { \& gathering } \\
\text { information) }\end{array}$} & \multirow[b]{2}{*}{$\begin{array}{c}\text { II } \\
\text { Search }\end{array}$} & & & $\begin{array}{l}\text { II } \\
\text { Search pro- } \\
\text { cess }\end{array}$ & $\begin{array}{c}\text { II } \\
\text { Info Search }\end{array}$ & $\begin{array}{c}\text { II } \\
\text { Information } \\
\text { search }\end{array}$ \\
\hline & $\begin{array}{c}\text { III } \\
\text { Application } \\
\text { Decision }\end{array}$ & & & & & $\begin{array}{l}\text { III } \\
\text { Information } \\
\text { gathering }\end{array}$ & $\begin{array}{l}\text { III } \\
\text { Alternative } \\
\text { Evaluation }\end{array}$ & $\begin{array}{l}\text { III } \\
\text { Evaluation } \\
\text { of alterna- } \\
\text { tives }\end{array}$ \\
\hline \multirow{2}{*}{$\begin{array}{l}\text { III } \\
\text { Evaluation } \\
\text { stage }\end{array}$} & $\begin{array}{c}\text { IV } \\
\text { Choice } \\
\text { Decision }\end{array}$ & $\begin{array}{c}\text { III } \\
\text { Process of } \\
\text { applying }\end{array}$ & \multirow{2}{*}{$\begin{array}{l}\text { III } \\
\text { Choice } \\
\text { (which } \\
\text { college to } \\
\text { attend) }\end{array}$} & & & $\begin{array}{c}\text { IV } \\
\text { Sending } \\
\text { Application }\end{array}$ & $\begin{array}{c}\text { IV } \\
\text { Purchase \& } \\
\text { Consump- } \\
\text { tion }\end{array}$ & $\begin{array}{c}\text { IV } \\
\text { Purchase \& } \\
\text { Consump- } \\
\text { tion }\end{array}$ \\
\hline & $\begin{array}{c}\mathrm{V} \\
\text { Matriculati- } \\
\text { on Decision }\end{array}$ & $\begin{array}{c}\text { and } \\
\text { enrolling }\end{array}$ & & & & $\begin{array}{c}\mathrm{V} \\
\text { Enrolling }\end{array}$ & $\begin{array}{c}\mathrm{V} \\
\text { Post-con- } \\
\text { sumption } \\
\text { Evaluation }\end{array}$ & $\begin{array}{l}\mathrm{V} \\
\text { Post-con- } \\
\text { sumption } \\
\text { evaluation }\end{array}$ \\
\hline
\end{tabular}


been technologically improved, enabling potential students to gather information globally and simultaneously, the separation as well as the formation of a fixed set of alternatives before searching will not be considered appropriate anymore.

Decision making takes place in the third stage, whereby some researchers separate this stage into a pre-purchase stage "Evaluation of Alternatives" and a purchase stage "Application Decision". In the later stage PIS have to decide, whether, when, what for and where to apply (Vrontis et al. 2007). At this stage, a high involvement from students can be assumed (Nicholls et al. 1995, Cubillo et al. 2006). This supports the separation of a pre-purchase and purchase stage according to the Contemporary Model by Vrontis et al. (2007) and Oliveira \& Soares (2016).

Furthermore, the purchase stage may be divided into three sub-stages: Applying (Chapman 1986, Hanson \& Litten 1989, Vrontis et al. 2007); Matriculation Decision (Chapman 1986) and Enrolling (Hanson and Litten 1989; Vrontis et al. 2007). As a large majority of PIS apply on average to $5 \mathrm{HEI}$ (QS Enrolment Solutions 2018), an equation of applying and enrolling may be considered as unrealistic. Therefore, a separation of the purchase stage into "Applying at an HEI abroad" and "Confirmation" is considered suitable. The later includes matriculation decisions as well as enrolling at an $\mathrm{HEl}$ overseas. Chapman (1986) integrated "Matriculation Decision" to take the likeliness of changed circumstances into account due to timing differences between application (spring) and matriculation (fall). Additionally, a majority of college-choice research supports the idea, that "inaccurate or incomplete information may affect a student's decision, the decision would still be rational provided that it was based on a reasoned reaction to the information available to them at the time that they made the decision" (Des)ardins \& Toutkoushian: 2005: 218). The final stage indicates a "Post-Choice Evaluation" of the experienced education abroad (Oliveira \& Soares 2016, Vrontis et al. 2007). This stage will not be examined in further research, as the focus lies upon initial decisions.

Within the course of the investigation a close alignment of more recent concepts with the classical consumer decision-making process can be stated. We strongly support the comparability of consumer decision-making processes for complex services with the decision making of PIS on foreign educational products. Yet, we would recommend further specifying the generic concept in two aspects:

(1) Firstly, none of the existing concepts integrated feedforward and feedbackward interrelations between all stages of the decision making process. However, both exist within the classical buying process (Tyagi \& Kumar 2004) as well as in real life: Through this process, the aspiration to study abroad may be narrowed down to a set of potential countries based on the gained information about visa requirements. And following a rather rational approach of decision making, the ideal process assumes that the gathered information will influence the evaluation \& choice of prospective HEI by the PIS.

(2) Secondly, the decision-making process must include the consideration set of potential HEls within students' choice. Due to the internationalization of the education market (e.g. by the Bologna Reform), the mass adoption of the internet, as well as the penetration of mobile technologies, there is a huge offer of study programs and simply too much information out there. Following Shocker et al (1991), we assume that students' "decision making is based upon hierarchal or nested sets of alternatives which [...] are processed by the decision maker prior to choice" (Shocker et al. 1991: 182). All potential solutions (study programs, HEls, countries etc.) which in general satisfy the need to study abroad shape the universal set of a PIS. Although information searching has been improved, it can be assumed that PIS may not know about all existing solutions. Instead, their decision making will be limited to the solutions which they come across or know about (=awareness or knowledge set) (Donkers 2002). From this set the consideration set evolves, which holds all acceptable alternatives or solutions for later consideration in decision making (Chapman 1986). The consideration set is purposefully constructed, influenced by context factors and outcomes of decision-making stages. The application set consists of the most relevant solutions (= choices) which the PIS will select from the consideration set and where students are going to apply. (Chapman 1986, Jackson 1982, Hossler \& Gallagher 1987, Shocker et al. 1991)

Upon that stage of research, the decision-making process of PIS will be shaped as presented in Fig. 1. This cycle of stages will be used in further research on the influencing factors of students' decision- making.

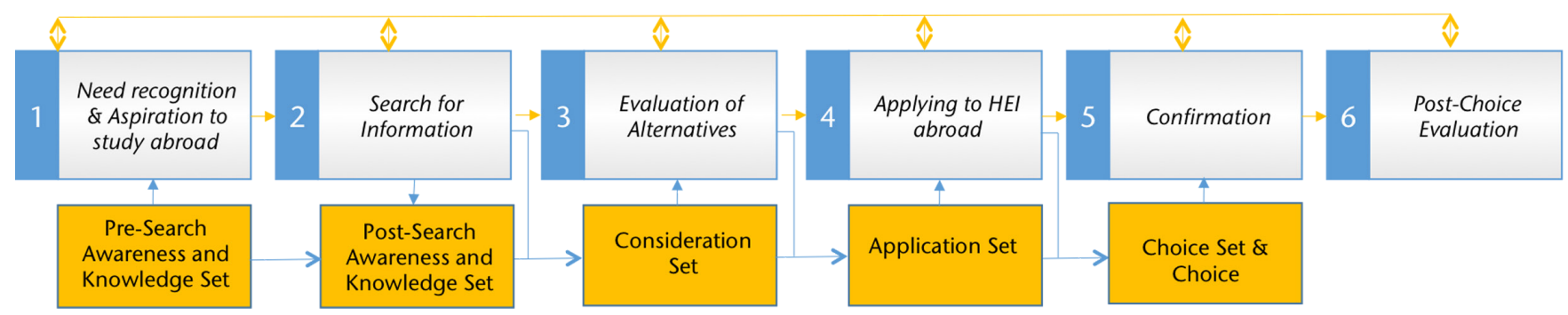

Fig. 1) Generic theoretical concept on the stages of the decision-making process of PIS. 


\subsubsection{Influencing parameters of the decision-making process of pros- pective international students}

Looking at the type of influencing factors, it needs to be stated that combined or complementary models dominate the research. All concepts include indicators from economic as well as sociological models. Economic concepts build on the economic model of human capital investment, whereas student investments in education are a result of a comparison of expected lifetime monetary and non-monetary benefits and expected cost (Perna 2006). Although students will certainly face incomplete or incorrect information, this approach follows a rational behavior pattern in decision making (DesJardins \& Toutkoushian 2005). Sociological models try to explain the influence of socioeconomic backgrounds on students' choices (Perna 2006). As both concepts have their limitations, a combination is viewed beneficially in the literature (Perna 2006).
With respect to stages 1-5 of the developed generic theoretical concept on the decision-making process of PIS (see Fig. 1), all stated parameters were gathered and classified by applying content analyses. Notwithstanding the high relevance of the concept by Oliveira \& Soares (2016), it must specifically be addressed here that their plotted concept stated fewer parameters than they discussed previously. Within our studies we integrated only the parameters plotted (see Oliveira \& Soares 2016: 138, Tab. 4).

\section{Stage 1 - Need recognition \& Aspiration to study abroad:}

With respect to the first stage, four main factors are considered in the literature: (a) Individual Factors, (b) Environment, (c) HEl as well as (d) High School (Hanson \& Litten 1989, Jackson 1982, Oliveira \& Soares 2016, Vrontis et al. 2007). Except for the contemporary model by Vrontis et al. (2007), all parameters are specifically related to influencing aspirations to study (abroad).
As some concepts represent generic works, a broad agreement is no surprise. Yet, a more applicable classification was derived from content analysis. Student characteristics, personal as well as motivational attributes, represent individual factors. From our point of view, environmental factors shall be further separated into home-country specific and destination-country specific factors, as varying conditions across countries may pull (better occupational or economic conditions in foreign country), or push (lack of opportunities to study in domestic area, censorship etc.) human capital abroad (Oliveira \& Soares 2016). Unfortunately, the influence of HEl was not pointed out in the concept by Oliveira and Soares (2016). The presented parameters are considered relevant for study decisions in general (Hanson \& Litten 1989, Hossler \& Gallagher 1987, Vrontis et al. 2007). By looking at empirical studies in chapter 3 , the influence of the main characteristics of foreign HEI will be further investigated. The impact of the attended high school is

Tab. 4) Influencing factors on stage „Need recognition \& Aspiration to study abroad” (based on Jackson 1982, Hanson \& Litten 1989, Hossler \& Gallagher 1987, Vrontis et al. 2007, Oliveira \& Soares 2016).

\section{(a) Individual Factors}

A1: Student Characteristics: race, income/resources, socioeconomic status, parent's education/job, family culture/ background, religion, sex, proximity to a university at home country

\section{A2: Personal Attributes:} class rank, academic ability/ aptitude, students/academic performance/achievements, self-image; personal value, benefits sought, personality, lifestyle/social context, educational aspirations

A3: Motivational Attributes: outcome of international experience

\section{(b) Environment}

\section{B1: Home Country}

B1a: General

occupational structure; eco-

nomic conditions, cultural conditions

B1b: Public Policy Aid

B1c: Influences/Media parents, career, neigh-borhood, counsellors, peers, communications, college officers
B2: Destination Country
B2a: General
occupational structure; eco-
nomic conditions, cultural conditions
geographical location destinati-
on country; cost of living
B2b: Public Policy Aid
B2c: Influences/Media:
social references and personal recommendations (parents, peers), available info destinati- on country

\section{(c) HEI}

C1: Characteristics: cost/ financial aid; size \& location; control (public/private); program availability

\section{C2: Actions:}

recruitment activities; admissions policies; aid granted; communications

\section{(d) High schoo}

D1: High School Characteristics: social composition; quality; curriculum; programs

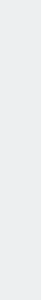


only addressed by concepts focusing on students in general, not on PIS. For the decision making process of PIS this factor is viewed as subordinate as it mainly influences the decision to study in general.

\section{Stage 2 - Search for Information:}

Five out of seven concepts listed relevant factors influencing students' search (Chapman 1981, 1986, Hanson \& Litten 1989, Hossler \& Gallagher 1987, Vrontis et al. 2007, Oliveira \& Soares 2016). According to these concepts, five relevant factors have to be considered: (a) Individual Factors; (b) HEl-Activities; (c) Search activities performed by students; (d) Sources and (e) Pre-Search Awareness \& Knowledge Set (see Fig. 2).

As described before, students start their search based on a "Pre-Search Awareness \& Knowledge Set" (=preliminary college value (Hossler \& Gallagher 1987)), that includes HEls which students came across in preceding periods. According to Hossler and Gallagher (1987), HEl-activities, search activities performed by students as well as existing sources influence each other. On the one hand, $\mathrm{HEl}$ carry out target group-specific marketing activities to search for students and, on the other hand, potential students search for relevant information about HEI. Following Vrontis et al. (2007) it can be assumed that individual determinants have an impact on the student's presearch awareness \& knowledge set and search activities, as well as sources used by the student.

\section{Stage 3 - Evaluation of Alternatives:}

The concepts by Jackson (1982), Perna (2006), Vrontis et al. (2007), Oliveira \& Soares (2016) deal with the evaluation of alternatives. Yet, only Jackson (1982) and Oliveira \& Soares (2016) speak of stage-specific evaluation criteria, like college costs, job-benefits/employability, HEl characteristics and influencers. Even though marketing departments of HEI may favor rational decision making and a fixed set of evaluation criteria for more efficient targeting, academics point out that "there is not one set course leading to college enrollment but that multiple routes are possible" (Perna 2006: 116).
Consequently, the concept by Perna combines economic and sociological models to the largest extent and puts an evaluation of expected benefits and costs in focus (Perna 2006: 115). Moreover "assessments of the benefits and costs are shaped not only by the demand for higher education and supply of resources to pay the costs but also by an individual's habitus and, directly and indirectly, by the family, school, and community context, higher education context, and social, economic, and policy context." (Perna 2006: 119). On this account, our classification of influencing factors follows the conceptual model by Perna (2006) adding factors which were specifically mentioned in other concepts (see Fig. 3).

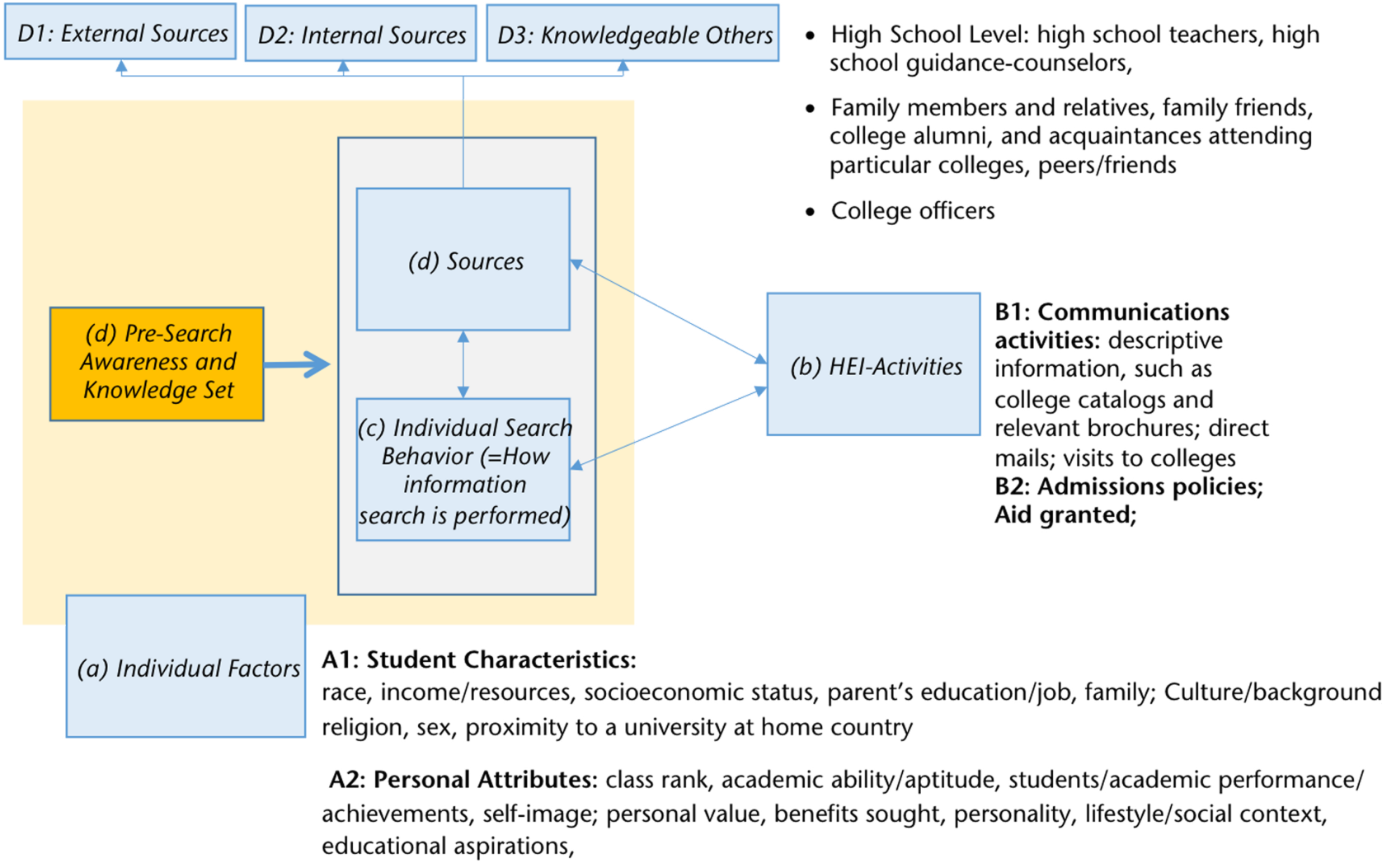

Fig. 2) Influencing factors on stage „Search for Information” (based on Chapman 1981, 1986, Hanson \& Litten 1989, Hossler \& Gallagher 1987, Vrontis et al. 2007, Oliveira \& Soares 2016). 
H: Social, economic and policy context

H1 General: demographic characteristics of the population, occupational structure; economic conditions, cultural conditions

H2: public policy characteristics, like policies and structures, that discourage, or encourage college enrollment

\section{G: HEl context}

G1: Characteristics: cost/ financial aid; size \& location; control (public/private); educational offer; reputation \& quality

G2: Actions: available info institution; recruitment activities; admissions policies; aid granted; communications

\section{F: School and community context}

F1: Availability of resources of high schools (quality; curriculum, assisting students in planning their career)

F2: Types of resources (like encouraging teachers)

F3: Structural supports and barriers, like gifted and talented programs

F4: Social composition

\section{E: Habitus}

E1: Customer attributes: race, income/resources; socioeconomic status; parent's education, family culture/background; religion: sex

E2: Personal Attributes: self-image; personal value; personality

E3: Cultural Capital (cultural knowledge and value placed on college attainment)

E4: Value of College Attainment (parents' educational attainment)

E5: Social capital (relationships between PIS and parents; between parents and school officials; and

between parents and student's friends' parents; information about college; parent's social networks on

college choice; peers with high educational expectations; assistance with college process

\section{C: Supply of resources:}

C1: Family income

C2: Financial Aid (need-based and non-need-based grants, subsidized and unsubsidized loans, work-study, and tuition tax credits)

\section{D: Demand for higher education}

D1: Academic preparation (level of coursework; class rank, academic ability/aptitude)

D2: Academic achievement (like test scores)

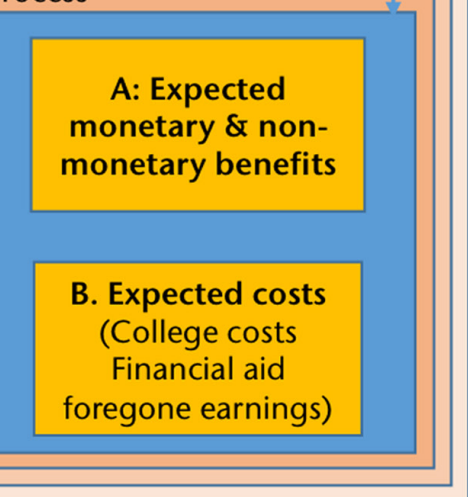

Fig. 3) Influencing factors on stage „Evaluation of Alternatives” (based on Jackson 1982, Perna 2006, Vrontis et al. 2007, Oliveira \& Soares 2016).

\section{Stage 4 - Applying at HEl abroad:}

Within the fourth stage, PIS will define their application set consisting of universities they are going to apply to (Chapman 1986). In that sense, Cubillo et al. (2006) use the term purchase intention, which "is defined as the intention of the student regarding the destination country as provider of the education service" (Cubillo et al. 2006: 104). According to our research the act of shaping the application set and sending applications will be influenced by: (a) individual factors; (b) locationspecific factors of the destination country \& city; (c) HEl; (d) high school and (e) student's expectations about the probability of admission (Chapman 1981, 1986, Hanson \& Litten 1989, Cubillo et al. 2006, Vrontis et al. 2007, see Tab. 5).

\section{Stage 5-Confirmation:}

The 5th stage of the decision-making process is of very high importance for both PIS and HEI: In that stage PIS make their inal "buying" decision about the educational product. For HEl, the definitive number (and quality) of freshmen and the final amount of public funding (based on the number of students) will be defined. Despite this importance, only the concepts by Chapman (1981 \& 1986), Hanson \& Litten (1989), Hossler \& Gallagher (1987) and the generic concept by Vrontis et al. (2007) have specifically addressed this stage within their research. As the generic concept by Vrontis et al. builds also upon models from the 1980-1990, research in that stage needs to be considered as rather outdated. Additionally, there is a broad consensus about the importance of $\mathrm{HEl}$ actions as an influencing factor within that stage. Yet, Hossler \& Gallagher (1987) highlight the limited impact of $\mathrm{HEl}$ at this point: “... most institutions are eliminate before they can really 'court ' prospective students" (Hossler \& Gallagher 1987: 218).

\section{Empirical studies on decision- making processes of prospective international students}

In the second stage of the review process, empirical data on the decision making of PIS was searched and examined to specify the stages or add further influencing factors in the derived theoretical generic model. A prioritization of the identified factors was also of interest within this research stage. The search for available empirical studies was carried out through database research via google using the key word 'international student survey'. The high 
Tab. 5) Influencing factors at the stage „Applying at HEl abroad” (based on Chapman 1981, 1986, Hanson \& Litten 1989, Cubillo et al. 2006, Vrontis et al. 2007).

\begin{tabular}{|c|c|c|}
\hline (a) Individual Factors & (b) Location & (c) HEI \\
\hline $\begin{array}{l}\text { A1: Student } \\
\text { Characteristics: } \\
\text { race, income/resources, } \\
\text { socioeconomic status, } \\
\text { parent's education/job, } \\
\text { family; } \\
\text { Culture/background, } \\
\text { religion, sex, proximity } \\
\text { to a university at home } \\
\text { country } \\
\text { A2: Personal } \\
\text { Attributes: class rank, } \\
\text { academic } \\
\text { ability/aptitude, students/ } \\
\text { academic } \\
\text { performance/achieve- } \\
\text { mentsself-image; personal } \\
\text { value, benefits sought, } \\
\text { personality, lifestyle/social } \\
\text { context, } \\
\text { personal improvement } \\
\text { ethnocentrism } \\
\text { educational aspirations }\end{array}$ & $\begin{array}{l}\text { B1: Destination Coun- } \\
\text { try } \\
\text { B1a: General } \\
\text { occupational structure; } \\
\text { economic conditions, } \\
\text { cultural conditions } \\
\text { geographical location } \\
\text { destination country; cost } \\
\text { of living } \\
\text { B1b: Public Policy Aid } \\
\text { B1c: Country Image } \\
\text { cultural proximity } \\
\text { social and academic } \\
\text { reputation } \\
\text { socioeconomic level } \\
\text { B1d: Influences/Media } \\
\text { parents, career, } \\
\text { neigh-borhood, counsel- } \\
\text { lors, peers, communica- } \\
\text { tions, college officers } \\
\text { B2: City } \\
\text { city dimension } \\
\text { city image } \\
\text { cost of living } \\
\text { environment }\end{array}$ & $\begin{array}{l}\text { C1: Characteristics } \\
\text { cost/ financial aid; size \& } \\
\text { location; control (public/ } \\
\text { private); } \\
\text { program availability; } \\
\text { proximity, ambiance, } \\
\text { C2: Actions: } \\
\text { recruitment activities; ad- } \\
\text { missions policies; admit/ } \\
\text { deny } \\
\text { aid granted; communi- } \\
\text { cations } \\
\text { written information } \\
\text { campus visits } \\
\text { communications } \\
\text { admission/recruiting } \\
\text { C3: Institution Image } \\
\text { quality of professors } \\
\text { institution's prestige } \\
\text { international recognition } \\
\text { communication } \\
\text { facilities on campus } \\
\text { C4: Programme } \\
\text { evaluation } \\
\text { programmes recognition } \\
\text { programmes suitability } \\
\text { programmes specializa- } \\
\text { tion } \\
\text { costs and finance }\end{array}$ \\
\hline
\end{tabular}

number of search results was reduced by the use of selection criteria such as the year of publication (no older than five years) or the focus of the survey on the European higher education market. Studies focused on one specific country or region of origin of PIS were eliminated since differences between nationalities were not in focus of our research. Based on these criteria five studies were selected as shown in Tab. 6:

\subsection{Empirical findings on the decision making process}

The stages of the decision making process of PIS were addressed within the studies by Hobsons EMEA (2014) and QS Enrolment Solutions (2017 \&
2018). With a focus on PIS enquiring to study in the UK or Australia, a specific order of choice was identified by Hobsons EMEA (2014): "Course, then country, then institution: that is the order of an international student's decision-making process. Students select a course to study first, then they evaluate the country and only after doing that will they select the institution" (Hobsons EMEA 2014: 4). In a later study this fact was also proven for PIS interested in studying in Europe (QS Enrolment Solutions 2017: 7). The recent International Student Survey by QS Enrolment Solutions even strengthens the importance of "subject \& course" above the university.

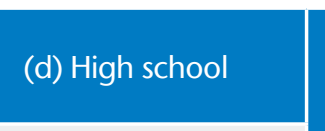

D1: High School Characteristics: social composition; quality; curriculum; programs

\subsection{Empirical findings on influencing factors}

Based on the theoretical generic concept of the decision-making process of PIS (see Fig. 2), all empirical studies were examined for influencing factors. The most important criteria considered by the students (top 5 or highlighted results by the authors) were taken into further consideration.

\section{Stage 1 - Need recognition \& Aspiration to study abroad:}

Only two of five studies have taken up influencing factors of the first stage. While QS Intelligence Unit (2016) addressed factors motivating PIS, the 
Tab. 6) Empirical studies on decision-making processes of PIS (Hobsons EMEA 2014, QS Enrolment Solutions 2017, 2018, QS Intelligence Unit 2016, 2018).

\begin{tabular}{|c|c|c|c|c|}
\hline Author & Year & Title & Sample & Focus of survey \\
\hline Hobsons EMEA & 2014 & $\begin{array}{l}\text { Beyond the data: } \\
\text { Influencing international } \\
\text { student decision making }\end{array}$ & $\begin{array}{l}18,393 \text { PIS who had enquired } \\
\text { to a UK or Australian higher } \\
\text { education institution }\end{array}$ & $\begin{array}{l}\text { decision-making process } \\
\text { of international students } \\
\text { aspiring to studying abroad }\end{array}$ \\
\hline $\begin{array}{c}\text { QS } \\
\text { Intelligence Unit }\end{array}$ & 2016 & $\begin{array}{l}\text { What Matters to } \\
\text { International Students? } \\
\text { Global Overview }\end{array}$ & $\begin{array}{l}1,800 \text { students in } \\
11 \text { countries globally }\end{array}$ & $\begin{array}{l}\text { common motivations and } \\
\text { priorities of PIS }\end{array}$ \\
\hline $\begin{array}{c}\text { QS } \\
\text { Enrolment Solutions }\end{array}$ & 2017 & $\begin{array}{l}\text { International Student } \\
\text { Survey Europe }\end{array}$ & $\begin{array}{l}18,706 \text { PIS from } 187 \text { countries } \\
\text { worldwide, interested in } \\
\text { studying in Europe }\end{array}$ & $\begin{array}{l}\text { international student } \\
\text { motivation and decision } \\
\text { making; communication } \\
\text { preferences and used } \\
\text { digital channels }\end{array}$ \\
\hline $\begin{array}{c}\text { QS } \\
\text { Intelligence Unit }\end{array}$ & 2018 & $\begin{array}{l}\text { Applicant Survey } \\
\text { 2018: What Drives an } \\
\text { International Student } \\
\text { Today? }\end{array}$ & 16,560 PIS & $\begin{array}{l}\text { motivations and decisions } \\
\text { higher education } \\
\text { applicants make, linked } \\
\text { to the current political } \\
\text { and economic context } \\
\text { in the US and Europe as } \\
\text { host countries for higher } \\
\text { education }\end{array}$ \\
\hline $\begin{array}{l}\text { QS } \\
\text { Enrolment Solutions }\end{array}$ & 2018 & $\begin{array}{l}\text { International Student } \\
\text { Survey European Union }\end{array}$ & $\begin{array}{l}22,838 \text { PIS who identified that } \\
\text { they are considering studying in } \\
\text { the following European coun- } \\
\text { tries: Germany, the Netherlands, } \\
\text { Sweden, France, Italy, Denmark, } \\
\text { Austria, Hungary, Spain, the } \\
\text { Czech Republic and Latvia }\end{array}$ & $\begin{array}{l}\text { international student } \\
\text { motivation and decision } \\
\text { making; communication } \\
\text { preferences and used digital } \\
\text { channels }\end{array}$ \\
\hline
\end{tabular}

QS Enrolment Solutions (2018) focused on concerns of PIS to study abroad:

\section{Stage 2 - Search for Information:}

Hobsons (2014), QS Enrolment Solutions (2017 \& 2018) inquired about factors of PIS while searching for and pre-evaluating potential foreign HEl. Alt- hough these studies did not put great emphasis on that stage, four factors could be derived: (1) social media; (2) website of $\mathrm{HEI}$, (3) response time of HEl after an enquiry and (4) agents. According to QS Enrolment Solutions (2018), 65\% of the PIS use social media platforms before they make an enquiry. In 2017, even $85 \%$ of the PIS stated they used so- cial media. With regard to the response time, PIS expect at least weekly contacts by the HEl after their enquiry (QS Enrolment Solutions 2017). The use of agents was only addressed by Hobsons EMEA (2014), whereby the study underlined that these third parties only play a role for about $10 \%$ of the respondents, mainly PIS of South East Asian nationality.
PIS from developing markets:

- $\quad$ study as an opportunity to access a better quality of education

- Access more specialized and established programs in their chosen field,

- contributing to the development of their own country,

- get a more internationally famous university on their CV,

- $\quad$ standing out in their own national employment market (employability)

PIS from developed markets:

- $\quad$ extended networking opportunities,

- improved employment prospects
\#1: Cost of living (80\%)

\#2: Availability of scholarships (69\%)

\#3: Finding accommodation (57\%)

\#4: Safety (57\%)

\#5: Getting a job (54\%) 
Stage $3 \& 4$ - Evaluation of alternatives \& Applying at $\mathrm{HEl}$ abroad:

According to the analyzed empirical studies, PIS follow a specific order in making their study choice: course - country - town - university (see section 3.1 ). Therefore, it's essential to look at the specific influencing factors of these sub-decision-making stages as we may assume they are also relevant criteria for evaluation.

Factors influencing the choice of field of study were addressed by QS Enrolment Solutions (2017, 2018). Both of these studies emphasized factors such as teaching quality, tuition fees as well as a high graduate employment rate. Among the relevant factors are also criteria such as the ranking of the course, good reputation as well as studying with like-minded people. By comparing both studies, it seems that in the latest report PIS put their personal development more in focus: $72 \%$ of PIS state that they chose their course based on their career planning. With respect to the high importance of this sub-decision stage further investigations are recommended.

With the exception of QS Intelligence Unit (2016), all studies contained factors influencing country selection. There are different factors of importance between 2014 and 2018. Due to this fact, it is not possible to derive an overall ranking. Instead a set of stated most relevant factors of PIS shall be provided:
"The considerations made when choosing a town or city to study in were similar. The top two most important factors were again considerations of teaching quality and the welcoming nature of the location" (QS Enrolment Solutions 2017: 9).

All studies included criteria to evaluate and choose foreign HEl. Factors which were identified majorly and are rather highly ranked by PIS include: (1) funding availabilities (scholarships) \& tuition fees; (2) academic reputation \& ranking (in a student's chosen subject \& global preferred) \& prestigious brand; (3) teaching quality; (4) course match to own expectations and (5) extent to which international students are welcomed. Additionally, entry requirements were mentioned by PIS interested in studying in the UK or Australia (Hobsons EMEA 2014) and $45 \%$ of PIS considering studying in European countries value good career service and links to employer (QS Enrolment Solutions 2018). QS Intelligence Unit (2016) researched that PIS sometimes meet difficulties assessing information they need to reach a thoughtful decision. Due to the fact that PIS will most likely search from abroad, the Digital Communication by $\mathrm{HEI}$ will influence their choice as well (QS Intelligence Unit 2016).

Recommendations, advice and feedback from others are an important source for PIS while making their decision (QS Enrolment Solutions 2017). In the latest report by QS Enrolment Solutions $60 \%$ of PIS stated that they had been affected by influencers at some stage. " $45 \%$ of them claiming that the experience of friends and family has influenced their choice of country
(1) Quality of education compared to home country/ teaching quality International recognition of qualification of guest country/ well-ranked universities

(4) Ease of getting a visa

(5) Good graduate employment options

\begin{tabular}{l}
$\begin{array}{l}\text { (2) Country's attitude to (3) Costs ( affordable cost } \\
\text { international students/ } \\
\text { safety of destination } \\
\text { country }\end{array}$ \\
$\begin{array}{l}\text { financial aid availability) } \\
\text { fing, scholarship/ }\end{array}$ \\
\hline
\end{tabular}

(6) Person-related reasons (cultural interest and lifestyle, institutions I'm interested in are located there) to study in." (QS Enrolment Solutions 2018: 17). QS Enrolment Solutions (2017) found, that parents, career advisors and career counsellors as well as friends are key influencers of PIS.

"The vast majority (73\%) will only consider five universities or fewer, this means that a significant proportion (27\%) are considering applying to six or more universities underlining the increased competition European universities face from their global competitors" (QS Enrolment Solutions 2018: 13). With regard to "Stage 4 - Applying at HEI abroad", students use and are influenced by Social Media (QS Enrolment Solutions 2017, 2018). Furthermore, $68.6 \%$ state in the early report to expect at least a weekly communication by $\mathrm{HEI}$. This is also expected by $78.7 \%$ of the PIS during "Stage 5 - Confirmation" (QS Enrolment Solutions 2017).

When comparing the results from the scoping analysis on theoretical concepts with the empirical results on the decision-making process of potential (international) students, the following conclusions can be drawn:

Both kind of sources must be viewed as useful complements of each single source as both offer advantages but hold limitations in respect to their use in educational marketing as well. Empirical studies provide clear recommendations to marketing departments of HEls but they do not map the full complexity of the context in which students make their choices. Thus, their marketing measures are based on a simpler image of conditions and may not be perfectly targeted at the needs, wishes, problems etc. of PIS. The advantage of complementary theoretical models, on the other hand, is the mapping of the "full" context of decision making processes. Yet, they do not offer hands-on recommendations for marketers and are simply too complex for daily use in marketing.

With regard to the first stage "Need recognition \& Aspiration to study abroad" empirical studies provide additional value, as they describe motivations, but also concerns of 
PIS in going abroad in more detail. This also counts for the "Search for Information" stage. Empirical studies are more recent in respect to (digital) communication behavior and expectations of PIS on the communication to/ from HEls.

Empirical studies did not differentiate between "Evaluation of Alternatives" and "Applying at HEl abroad." Yet they provide clear criteria for choice making, which can be considered relevant evaluation criteria as well. Additionally, these studies provided new knowledge on the size of the application set, the order of choice and the influence of new information and communication technologies. Based on the empirical findings, theoretically derived influencing factors on the decision making process may be prioritized.

\section{Summary model \& managerial implications for $\mathrm{HEl}$}

At this point a presentation of our generic concept, which is based on an aggregation of the gained knowledge on theoretical complementary models and empirical findings, is expected. However, our generic concept would be characterized by the same limitations as the existing theoretical concepts: too complex and less practiceoriented for use in HEl-Marketing. For this reason, we have tried to transfer our knowledge on the decision making process and its influencing factors to a practical marketing tool. The Buying Proforma by Dibb and Simkin was used as a basic framework as it is "built on the accepted best practice principles from the buying behavior literature and, over the years, has proved very successful in portraying the nature of the customer challenge" (Dibb \& Simkin 2008: 42). The Buying Proforma integrates (1) a Customer Profile; (2) Buying Center Composition (= people involved in the purchase and their respective roles); (3) Key Customer Values (= factors considered most important by customers); (4) Buying Process Mechanics (= steps involved in the buying process) and (5) the Core Influences (= any factors which have an influence on the buying decision) (Dibb \& Simkin 2008).
The developed Buying Proforma holds all the relevant information on a general PIS (s. fig. 6), making choices to study abroad. More relevant influencing factors which were highlighted in the empirical studies are in bold print. We advise marketing departments to use the provided proforma as a starting point and ask to develop target market specific proforma (PIS of a specific region or country in focus) and integrate their findings. Additionally, we hope our idea stimulates creative thinking about communication and service offers to PIS. Not to mention the opportunity to create more efficient marketing activities by considering pull (= marketing measures to create demand for studying abroad) as well as push (= focus on countries in which conditions support study abroad aspirations of PIS) dynamics in attracting PIS.

Nevertheless, our efforts have to be critically viewed as well. Firstly, there are limitations on the nature of the performed scoping study. Research was focused on English sources only and it will be necessary to investigate the importance of each influencing factor of a student's decision-making. With respect to those limitations, we recommend quantitative studies across students from different countries to verify our concept, develop target groupspecific buying proforma and to weigh the importance of factors. Secondly, we tried to reduce the complexity of decision-making processes by developing a Buying Proforma. To which extent the proposed proforma proves a better practicability also needs to be investigated. 


\section{Customer Profile}

\section{PROFILE}

Student Characteristics: race, income/resources, socioeconomic status, parent's education/job, family; Culture/background, religion, sex, proximity to a university at home country

Personal Attributes: self-image; personal value; personality, benefits sought lifestyle/ social context, personal improvement, ethnocentrism, educational aspirations, cross-cultural interests

Demand for higher education:

Academic preparation (level of coursework; class rank, academic ability/aptitude)

Academic achievement (test scores)

Cultural \& Social capital

Value of College Attainment

\section{INFLUENCERS}

Private Level: Family members and relatives, family friends, college alumni, and acquaintances attending particular colleges, peers/friends, neighborhood

High School Level: teachers, guidance-counselors or college officers

\section{Education Agents}

\section{KEY CUSTOMER VALUES}

Outcome of international experience PIS from developing markets: - access a better quality of education, more specialized and established programs in chosen field

- contributing to the development of home country

get a more internationally famous university on $\mathrm{CV}$,

standing out in own national employment market (employability)

PIS from developed markets:

- extended networking opportunities, - improved employment prospects

\section{Influencing Factors}

Social, economic and policy context

\section{A. Home Country}

a: General: Occupational struc ture; Economic conditions, cultural conditions

b: Public Policy Aid

c: Media

B. Destination Country

a: General:

Occupational structure; Economic conditions, cultural conditions, safety, job opportunities; Quality of education compared to home country/ teaching quality, International recognition of qualification of guest country/ well-ranked universities, Ease of getting a visa, Geographical location destination country; Cost of living Finding Accommodation, Countries attitude to international students/ safety of destination country

b: Public Policy Aid

c: Media: Available info destination country
High School Characteristics: Availability of resources of high schools (quality; curriculum, assisting students in planning their career)

Types of resources (like encouraging teachers)

Structural supports and bar-

riers, like gifted and talented

programs

Social composition

Individual Search Behavior (= How information search is performed)

Supply of resources:

Family income

Financial Aid (need-based and non-need-based grants, subsidized and unsubsidized loans, work-study, and tuition tax credits)
HE

Characteristics: Cost/ Fi-

nancial Aid; Size \& Location; Control (public/private); Program availability; tuition fees, Extent to which international students are welcomed

Actions: Recruitment activities; Admissions policies; Aid granted; Communications

Communications activities: descriptive information, such as college catalogs and relevant brochures; direct mails; visits to colleges; Digital Communication (Social Media; Website), Response time of $\mathrm{HEl}$ after an enquiry Performance Indicators: teaching quality, graduate employment rate; ranking (in a student's chosen subject \& global preferred), reputation; studying with like-minded people

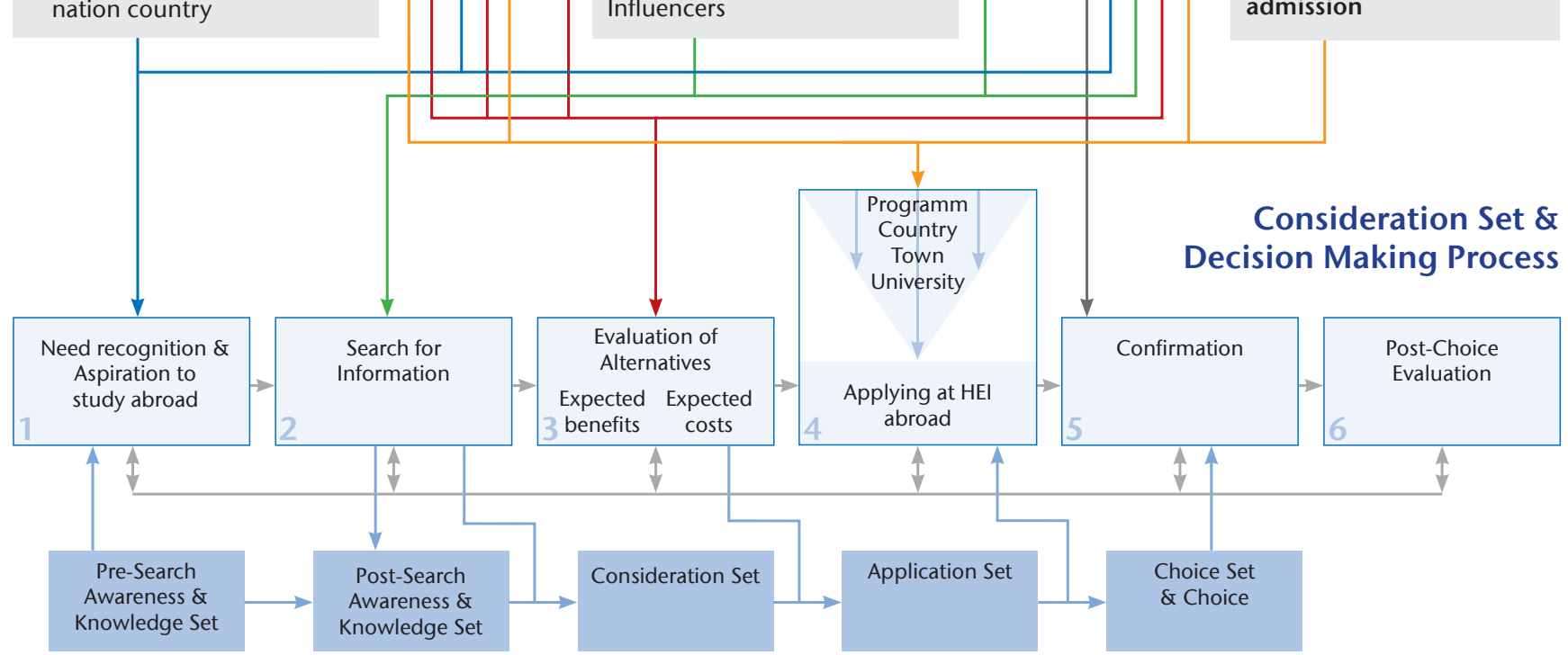




\section{REFERENCES}

Arksey H, O'Malley L (2005) Scoping studies: towards a methodological framework. International Journal of Social Research Methodology 8:19-32. doi: $10.1080 / 1364557032000119616$

Bagri NT (2017) The number of students globally has doubled since 2000 - and it's private colleges that are meeting the demand. https://qz.com/965664/the-number-ofstudents-globally-has-doubled-since-2000-and-its-privatecolleges-that-are-meeting-the-demand. Accessed 09 Jan 2019.

Binsardi A, Ekwulugo F (2003) International marketing of British education: research on the students' perception and the UK market penetration. Marketing Intelligence \& Planning 21(5):318-27

British Council (2012) The shape of things to come: highe education global trends and emerging opportunities to 2020. Going Global 1.

Chapman DW (1981) A model of student college choice. Journal of Higher Education 52(5): 490-505

Chapman RG (1986) Toward a theory of college selection: a model of college search and choice behavior. Advances in Consumer Research 13:246-250

Colquhoun HL, Levac D, O'Brien KK, Straus S, Tricco AC, Perrier L, Kastner M, Moher D (2014) Scoping reviews: time for clarity in definition, methods, and reporting. J Clin Epidemiol 67:1291-1294. doi: 10.1016/j.jclinepi.2014.03.013

Cubillo JM, Sánchez J, Cerviño J (2006) International students' decision-making process. International Journal of Educational Management 20:101-115.

doi: $10.1108 / 09513540610646091$

DesJardins SL, Toutkoushian RK (2005) Are students really rational? The development of rational thought and its application to student choice. In Smart JC (ed.) Higher Education: Handbook of Theory and Research 20, Kluwer Academic Publishers, Dordrecht, 191-240

Dibb S, Simkin L (2008) Marketing planning: A workbook for marketing managers. South-Western Cengage Learning, London

Donkers B (2002) Modeling consideration sets across time: The relevance of past consideration. American Marketing Association. Conference Proceedings, suppl. 2002 AMA Winter Educators' Conference 13

Euromonitor International (2017) Current Trends in the Global Education Sector. https://www.euromonitor.com/ current-trends-in-the-global-education-sector/report. Accessed 09 Jan 2019.

Farjam S, Hongyi X (2015) Revising Students' Decisionmaking Process. The International Journal of Management Science and Business Administration 1:70-78. doi: 10.18775/ijmsba.1849-5664-5419.2014.110.1006

GATE-Germany (2018a) gate-germany.de. https://www. gate-germany.de/. Accessed 09 Jan 2019.

GATE-Germany (2018b) Netzwerk-Konferenz. https:// www.gate-germany.de/konferenzen/netzwerk-konferenz. html. Accessed 09 Jan 2019.

Hanson K, Litten L (1989) Mapping the Road to Academia: A Review of Research on Women, Men, and the College Selection Process. The undergraduate woman: Issues in education P. Perun:73-98

Hemsley-Brown J, Oplatka I (2006) Universities in a competitive global marketplace: A systematic review of the literature on higher education marketing. International Journal of Public Sector Management 19:316-338. doi: $10.1108 / 09513550610669176$

Hobsons EMEA (2014) Beyond the data: Influencing international student decision making. https://www. hobsons.com/res/Whitepapers/23 Beyond_The_Data_lnfluencing_International_Student_Decision_Making.pdf. Accessed 09 Jan 2019
Hossler D, Gallagher K (1987) Studying student college choice: A three-phase model and the implications for the policymakers. College and University 2(3), 207-221

Jackson GA (1982) Public Efficiency and Private Choice in Higher Education. Educational Evaluation and Policy Analysis 4:237-247. doi: 10.2307/1164016

Ken Research (2011) Global Education Sector and Changing Trends. https://www.kenresearch.com/educationand-recruitment/education/global-education-marketresearch-report/139-99.html. Accessed 09 Jan 2019.

Kotler P, Armstrong G, Wong V, Saunders J (2008) Principles of marketing, 5th European ed. Financial Times Prentice Hall, Harlow.

Nicholls J, Harris J, Morgan E, Clarke K, Sims D (1995) Marketing higher education: the MBA experience. The International Journal of Educational Management 9(2):31-8

OECD (2018) Education at a Glance 2018: OECD Indicators. OECD Publishing, Paris.

Oliveira D, Soares AM (2016) Studying abroad: developing a model for the decision process of international students. Journal of Higher Education Policy and Management 38:126-139.

doi: $10.1080 / 1360080 \times 2016.1150234$

Perna LW (2006) Studying college access and choice: a proposed conceptual model. In: Smart JC (ed) Higher Education, vol 21. Kluwer Academic Publishers, Dordrecht, pp 99-157

QS Enrolment Solutions (2017) International Studen Survey 2017: Welcoming the World. Europe. https://www. internationalstudentsurvey.com/international-studentsurvey-2017/. Accessed 09 Jan 2019.

QS Enrolment Solutions (2018) International Student Survey 2018: Harnessing Opportunities in Global Higher Education. EU. https://www.internationalstudentsurvey. com/international-student-survey-2018/. Accessed 09 Jan 2019

QS Intelligence Unit (2016) What Matters to Internationa Students? Clobal Overview. https://www.topuniversities. com/student-info/qs-guides/what-matters-internationalstudents-overview. Accessed 09 Jan 2019.

QS Intelligence Unit (2018) QS Applicant Survey 2018 What Drives an International Student Today? https:// www.topuniversities.com/student-info/qs-guides/qsapplicant-survey-2018-what-drives-international-studenttoday. Accessed 09 lan 2019.

Shocker AD, Ben-Akiva M, Boccara B, Nedungandi P (1991) Consideration Set Influences on Consumer Decision Making and Choice: Issues, Models, and Suggestions. Marketing Letters 2(3):181-197

Statista (2018) Anteil der ausländischen Studienanfänger/innen an Universitäten in Deutschland in den Studienjahren* von 2004 bis 2016. https://de.statista.com/statistik/ daten/studie/199075/umfrage/anteil-der-auslaendischenstudienanfaenger-in-deutschland/. Accessed 09 Jan 2019.

Tyagi CL, Kumar A (2004) Consumer Behaviour. Atlantic Publishers and Distributors, New Delhi, India.

UNESCO (2017) Six ways to ensure higher education leaves no one behind. Global Education Monitoring Report: Policy Paper.

Vrontis D, Thrassou A, Melanthiou Y (2007) A contemporary higher education student-choice model for developed countries. Journal of Business Research 60:979-989. doi: 10.1016/j.jbusres.2007.01.023

Watjatrakul B (2014) Factors affecting students' intention to study at universities adopting the "student-as-customer" concept. International Journal of Educational Management 28:676-693. doi: 10.1108/IJEM-09-2013-0135

\section{AUTHORS}

Prof. Dr. Sandra Haas Florence Terryn, M.A.

International Management / Marketing

Technische Hochschule Wildau

E-Mail for correspondence: sandra.haas@th-wildau.de

\section{ब.0}

